\title{
Vitamin D Supplementation in Tuberculosis Patients: A Cross Sectional Study
}

\author{
Dina Keumala Sari ${ }^{1 *}$, Nurfida Khairina Arrasyid ${ }^{2}$, Y. S. Harahap ${ }^{3}$ \\ ${ }^{1,2}$ Faculty of Medicine, Universitas Sumatera Utara \\ ${ }^{3}$ Teladan Community Health Service, Sumatera Utara, Indonesia
}

\begin{abstract}
Previous studies have not been able to show with certainty the effect of vitamin D supplementation in tuberculosis patients. The objective of this study is to determine whether vitamin D supplementation to patients with tuberculosis could influence 25hydroxyvitamin $\mathrm{D}(25(\mathrm{OH}) \mathrm{D})$ and calcium serum levels. The results, after 28 days, the vitamin D supplementation showed significant increase of $25(\mathrm{OH}) \mathrm{D}$ serum level at the end point $(\mathrm{p}=0.001)$, but not for the calcium serum level $(\mathrm{p}=0.3)$. The Conclusions is supplementation with 1,000 IU vitamin D per day increased the $25(\mathrm{OH}) \mathrm{D}$ serum level but there was no association with the calcium serum level.
\end{abstract}

Keyword: Calcium, Tuberculosis, Vitamin D

Abstrak. Penelitian sebelumnya belum dapat menunjukkan dengan pasti efek suplementasi vitamin D pada pasien tuberkulosis. Tujuan dari penelitian ini adalah untuk menentukan apakah suplementasi vitamin D pada pasien dengan TB dapat mempengaruhi 25hydroxyvitamin $D(25(\mathrm{OH}) \mathrm{D})$ dan tingkat serum kalsium. Hasilnya, setelah 28 hari, suplementasi vitamin $D$ menunjukkan peningkatan yang signifikan dari level serum 25 (OH) D pada titik akhir $(p=0,001)$, tetapi tidak untuk level serum kalsium $(p=0,3)$. Kesimpulannya adalah suplementasi dengan 1.000 IU vitamin D per hari meningkatkan kadar serum $25(\mathrm{OH})$ D tetapi tidak ada hubungan dengan kadar serum kalsium.

Kata Kunci: Kalsium, Tuberkulosis, Vitamin D

Received [date month year] | Revised [date month year] | Accepted [xx Month xxxx]

\section{Introduction}

Vitamin D supports induction of pleiotropic antimicrobial responses in tuberculosis patient, resulting from an immunomodulatory effect (Coussens, 2012). Vitamin D supplementation accelerates sputum smear conversion and enhanced tuberculosis (TB) treatment (Martineau, 2011; Siempos, 2008). Vitamin D is also known to be essential to Mycobacterium tuberculosis containment and killing through activation of 25-hydroxyvitamin D receptors presents on all immune cells (Liu 2006).

\footnotetext{
*Corresponding author at: Faculty of Medicine, Universitas Sumatera Utara, Jl. Dr. Mansur No. 5, Kampus USU, Medan, Sumatera Utara, Indonesia, 20155

E-mail address: dina@usu.ac.id
} 
Deficiency vitamin D found in healthy people, especially women in the tropical country (Sari, 2017a; Sari, 2017b). Low sunlight exposure, vitamin D intake, physical activity, and vitamin D receptor gene polymorphism are risk factors for vitamin D deficiency (Sari, 2017c) However, low 25(OH)D serum level did not affect calcium serum level (Sari, 2017d).

Calcium signaling in tuberculosis infection plays a significant role in the pathogenesis of TB (Sharma, 2017). Calcium also is known as a ubiquitous second messenger that could control multiple processes and is included in cellular activities like division, motility, stress response, and signaling. However, $\mathrm{Ca}$ is thought to be a regulative molecule regarding TB infection but its binding relation with proteins which are influenced by $\mathrm{Ca}$ concentrations in host-pathogen (Chan, 2017). Therefore, we conducted a clinical trial to determine the effect of $1000 \mathrm{IU}$ vitamin D for 28 days to $25(\mathrm{OH}) \mathrm{D}$ and calcium serum level.

\section{Method}

The objective of this study is to determine the effect of 1000 IU per day vitamin D supplementation for 28 days to $25(\mathrm{OH}) \mathrm{D}$ and calcium serum level in tuberculosis patients who lived in three community health center in Medan City, North Sumatera, Indonesia between June to September 2017. This is a randomized control trial including 48 patients, 24 tuberculosis patients for vitamin D supplementation and placebo group.

The subjects of this study consisted tuberculosis patients in community health centers with the higher tuberculosis prevalence in Medan, North Sumatera, Indonesia, man, and women with various occupations, and taken purposively; there were 32 subjects The inclusion criteria were tuberculosis patients within the range of 18-60 years old. Exclusion criteria were subjects with the history of diabetes mellitus, myocardial infarction, renal or liver dysfunction. In addition to those exclusion criteria, subjects who were pregnant and lactating were also excluded.

We measured 25(OH)D serum concentration by chemiluminescent immunoassay (CLIA) technology (Diasorin, Stillwater, MN), measures were between 4.0 and $150 \mathrm{ng} / \mathrm{mL}$. The lowest value was $4.0 \mathrm{ng} / \mathrm{mL}$ which is based on an inter-assay precision $3.90 \% \mathrm{CV}$. Reference range were $<20 \mathrm{ng} / \mathrm{mL}$ categorized deficiency, 20-30ng/mL (insufficiency), 30-100 ng/mL (sufficiency) (Hollick, 2007). To convert $\mathrm{ng} / \mathrm{mL}$ to $\mathrm{nmol} / \mathrm{L}$ is multiply with 2.496. Calcium serum was measured by ADVIA Bayer Assayed Chemistry Controls, with principle procedure: calcium ions form a violet complex with o-cresolphthaleincomplexone in an alkaline medium. The reaction is measured at 545/658 nm, and normal concentration of calcium was 8.3$10.6 \mathrm{mg} / \mathrm{dL}$.

Continuous variables were expressed as continuous variables as means \pm SDs. Categorical variables were expressed as percentage proportions, using chi-square to expressed significant difference between two groups, and Fischer test if the data did not meet the criteria. The $p$ 
values $<0.05$ were considered statistically significant. We used SPSS program (version 11.5; SPSS Inc, Chicago, IL) to perform the analysis.

This study was carried out after ethical approval was obtained from the Health Research Ethics Committee of Sumatera Utara University Medical School (No. 264/TGL/KEPK FK USU-RSUP HAM/2017) and all participants were given written informed consent to the study procedures.

\section{Results}

\subsection{Characteristics of Subjects}

Table 1 shows the characteristics of the two groups, one receiving vitamin D supplementation and the other a placebo; there were no significant differences between the two groups.

Table 1 Demographic and lifestyle characteristics of subjects before intervention

\begin{tabular}{llll}
\hline Characteristic & $\begin{array}{l}\text { Intervention } \\
\text { (D) Group } \\
(\mathrm{n}=24)\end{array}$ & $\begin{array}{l}\text { Control (C) } \\
\text { Group } \\
(\mathrm{n}=24)\end{array}$ & $p$-value \\
\cline { 2 - 3 } & $37 \pm 2.5$ & $33.8 \pm 9.1$ & 0.4 \\
\hline $\begin{array}{l}\text { Age (years) } \\
\text { Body mass index } \\
\left(\mathrm{kg} / \mathrm{m}^{2}\right)^{1}\end{array}$ & $19.8 \pm 3.9$ & $20.3 \pm 3.1$ & 0.2 \\
$\begin{array}{l}\text { Serum 25(OH)D } \\
(\mathrm{ng} / \mathrm{mL})^{1}\end{array}$ & $19.7 \pm 6.6$ & $19.3 \pm 4.6$ & 0.1 \\
$\begin{array}{l}\text { Serum calcium } \\
(\mathrm{mg} / \mathrm{dL})^{1}\end{array}$ & $9.0 \pm 0.5$ & $9.1 \pm 0.5$ & 0.3 \\
\hline
\end{tabular}

Table 2 shows the difference before and after intervention in the intervention group. After supplementation, there was a significant increase in vitamin D intake, while there was no significant difference in any of the nutrient intakes in the Control Group.

Table 2 Energy and nutrient intake of subjects before and after intervention in D group

\begin{tabular}{lccc}
\hline Nutrient intake & \multicolumn{3}{c}{ Intervention (D) group $(\mathrm{n}=24)$} \\
\cline { 2 - 4 } & Before & After & $p$-value \\
\hline Energy (kcal) & 710.3 & 760.9 & 0.25 \\
Protein $(\mathrm{g})$ & 25.4 & 28.3 & 0.10 \\
Calcium $(\mathrm{mg})$ & 219.1 & 198.4 & 0.47 \\
Vitamin D $(\boldsymbol{\mu g})$ & $\mathbf{3 . 6}$ & $\mathbf{3 1 . 1}$ & $\mathbf{0 . 0 1}$ \\
\hline
\end{tabular}


Table 3 shows the difference between before and after intervention in both groups, after supplementation, there was significant increase in vitamin D intake, while there was no significant difference with all the nutrients intake in Control Group.

Table 3 Mean serum 25(OH)D and calcium levels before and after intervention

\begin{tabular}{llll}
\hline Variable & Baseline & Endpoint & $p$ value $^{2}$ \\
\hline $\begin{array}{l}\text { Serum 25(OH)D } \\
(\text { ng/mL) }\end{array}$ & & & \\
$\begin{array}{l}\text { Intervention (D) } \\
\text { group }\end{array}$ & $\begin{array}{l}19.7 \pm 6 . \\
6\end{array}$ & $27.3 \pm 3.1$ & $\mathbf{0 . 0 4}$ \\
$\begin{array}{l}\text { Control (C) group } \\
19.3 \pm 4 .\end{array}$ & $21.9 \pm 2.4$ & 0.01 \\
& 6 & $\mathbf{0 . 0 1}$ & \\
$p$ value $^{1}$ & & & \\
$\begin{array}{l}\text { Serum calcium } \\
\text { (mg/dL) }\end{array}$ & $9.0 \pm 0.5$ & $8.9 \pm 0.3$ & 0.34 \\
$\begin{array}{l}\text { Intervention (D) } \\
\text { group }\end{array}$ & $9.1 \pm 0.5$ & $\begin{array}{l}8.9 \pm 0.4 \\
\text { Control (C) group }\end{array}$ & 0.1 \\
$\begin{array}{l}p \text { value } \\
\text { ( }\end{array}$ & 9.5 & \\
\hline
\end{tabular}

\section{Discussion}

Vitamin D helps the body effectively absorb calcium; there is an interaction between vitamin and mineral. Calcium is known as a ubiquitous second messenger that could control multiple processes and have a role in tuberculosis infection and significant role in pathogenesis.

Calcitriol, the active metabolite of vitamin $\mathrm{D}$, induce innate antimicrobial responses and suppresses proinflammatory cytokine responses in vitro (Martineau, 2007). This microbial activity is mediated via induction of reactive nitrogen intermediates, reactive oxygen intermediates, antimicrobial peptides, and autophagy (Hewison, 2011).

These studies have a similar report with previous studies that in tuberculosis patient found vitamin D deficiency (Martineau, 2011; Salahuddin, 2013). However, after vitamin D supplementation, patients with baseline categorized in deficiency resulting greater weight gain and more rapid radiographic clearing of disease as compared to placebo (Salahuddin, 2013; Sari, 2017d).

The previous study showed that high dose of vitamin D which is in that study was $600.000 \mathrm{IU}$ vitamin D intramuscular accelerated clinical, radiographic improvement in all tuberculosis patients and increased host immune activation, but the length of the study reached 12 weeks (Salahuddin, 2013). In this study, length of the study was 28 days (4 weeks), and tuberculosis patient received $1000 \mathrm{IU}$ oral vitamin D supplementation per day. However, this study also showed an increased of $25(\mathrm{OH}) \mathrm{D}$ serum level at the end point. 
Hypercalcemia found in tuberculosis patient; the previous study confirmed that serum calcium is raised in tuberculosis, but the effect may be reduced by a low calcium intake and a low parathyroid hormone level. Although the calcium and vitamin D metabolism appeared to be altered in tuberculosis, no direct relationship between serum calcium and 1,25(OH)2D, was found (Chan, 2017). Our study reported normal calcium serum level and no significant different before and after vitamin $d$ supplementation. But we found that serum

Our study had limitations; we did not assess parathyroid hormone and other clinical tuberculosis parameters such as chest X-Ray, and blood examination (C-reactive protein).

\section{Conclusion}

From the study results, it can be concluded that in tuberculosis patient there were the deficiency and insufficiency vitamin $\mathrm{D}$, but calcium serum level in normal level. No association found between $25(\mathrm{OH}) \mathrm{D}$ and calcium serum level.

\section{Acknowledgments}

The authors gratefully acknowledge that the present research is supported by Ministry of Research and Technology and the Higher Education Republic of Indonesia, Research and Community Service, Universitas Sumatera Utara.

\section{REFERENCES}

Coussens AK, Wilkinson RJ, Hanifa Y, Nikolayevsky V, Elkington PT, Islam K, Timms PM, Venton TR, Bothamley GH, Packe GE, Darmalingam M, Davidson RN, Milburn HJ, Baker LV, Barker RD, Mein CA, Bhaw-Rosen L, Nuamah R, Young DB, Drobniewski FA, Griffiths CJ, Martineau AR, 2012. Vitamin D accelerates resolution of inflammatory responses during tuberculosis treatment. PNAS. 109, 15449-15454.

Hewison M, 2011. Antibacterial effects of vitamin D. Nat Rev Endocrinol. 7:337-345.

Holick MF, 2007. Vitamin D deficiency. N Engl J Med. 357 266-281.

Liu PT, Stenger S, Li H, Wenzel L, Tan BH, Krutzik SR, Ochoa MT, Schauber J, Wu K, Meinken C, Kamen DL, Wagner M, Bals R, Steinmeyer A, Zügel U, Gallo RL, Eisenberg D, Hewison M, Hollis BW, Adams JS, Bloom BR, Modlin RL, 2006. Toll-like receptor triggering of a vitamin D-mediated human antimicrobial response. Science. 311 (5768): 1770-3 [PubMed:16497887].

Martineau AR, Timms PM, Bothamley GH, Hanifa Y, Islam K, Claxton AP, Packe GE, Moore-Gillon JC, Darmalingam M, Davidson RN, Milburn HJ, Baker LV, Barker RD, Woodward NJ,Venton TR, Barnes KE, Mullett CJ, Coussens AK, Rutterford CM, Mein CA, Davies GR, Wilkinson RJ, Nikolayevskyy V, Drobniewski FA, Eldridge SM, Griffiths CJ, 2011. High-dose vitamin D3 during intensive phase treatment of pulmonary tuberculosis: a double-blind randomised controlled trial. Lancet. 15, 242-250.

Salahuddin N, Ali F, Hasan Z, Rao N, Aqeel M, Mahmood F, 2013. Vitamin D accelerates clinical recovery from tuberculosis: results of the SUCCINCT Study [Supplementary Cholecalciferol in recovery from tuberculosis]. A randomized, placebo-controlled, clinical trial of vitamin D supplementation in patients with pulmonary tuberculosis. BMC Infectious Diseases. 13:22. 
Sari DK, Tala ZZ, Lestari S, Hutagalung S, Ganie RA, 2017a. Vitamin D receptor gene polymorphism among Indonesian women in North Sumatera. Asian J. Clin. Nutr. 9(1) $44-50$.

Sari DK, Tala ZZ, Lestari S, Hutagalung S, Ganie RA, 2017b. Lifestyle differences in rural and urban areas affected the level of vitamin $\mathrm{D}$ in women with single nucleotide polymorphism in North Sumatera. Asian J. Clin. Nutr. 9(2) 57-63

Sari DK, Tala ZZ, Lestari S, Hutagalung S, Ganie RA, 2017c. Body mass index but not $25(\mathrm{OH}) \mathrm{D}$ serum is associated with bone mineral density among Indonesian women in North Sumatera: a cross-sectional study. Asian J. Clin. Nutr. 9(2) 37-43.

Sari DK, Tala ZZ, Lestari S, Hutagalung S, Ganie RA, 2017d. Vitamin D Supplementation in Women with Vitamin D Receptor Gene Polymorphisms: A Randomized Controlled Trial. Asian J. Clin. Nutr. 9(2) 89-96.

Sharma S, Meena LS, 2017. Potential of Ca in Mycobacterium tuberculosis HRv Pathogenesis and Survival. Appl. Biochem.Biotechnol. 181(2) 762-71.

Siempos II, Vardakas KZ, Kopterides P, Falagas ME, 2008. Adjunctive therapies for community-acquired pneumonia: a systematic review. J Antimicrob Chemother. 62: 661668. 